\title{
PEMBENTUKAN KULTUR AKHLAK MULIA DI KALANGAN MAHASISWA UNY MELALUI PEMBELAJARAN PAI
}

\author{
Marzuki \\ (FISE Universitas Negeri Yogyakarta, Karangmalang Yogyakarta, \\ E-mail: marzukiwafi@yahoo.co.id, HP.0818462597)
}

\begin{abstract}
Noble Character Culture Building Among Students of Yogyakarta State University Through PAI Learning. This study aims to reveal problems in PAI learning in Yogyakarta State University and its role in building students' noble character. This study was a qualitative study. The data were obtained through interviews, questionnaires, and documents and were analyzed using qualitative analysis techniques with the inductive approach. The results show that PAI learning has an important role in building students' noble character if supported by competent lecturers, good inputs, adequate materials, and good processes. Conversely, if such supports are not available, the goal will be difficult to attain. Among the problems are diverse student abilities, students' less attention to character, the emphasis of PAI learning materials on cognitive aspects, and difficulty in controlling students outside the class.
\end{abstract}

Keywords: culture building, noble character, PAI learning

\section{PENDAHULUAN}

Sebagian pengamat berpendapat bahwa mutu pendidikan di Indonesia tidak meningkat, bahkan cenderung menurun. Salah satu indikator adalah semakin banyaknya lulusan institusi pendidikan yang tidak dapat memiliki kesiapan dalam memasuki dunia kerja sesuai dengan ilmu dan bidang yang ditekuninya. Indikator lain yang lebih penting adalah menurunnya sikap dan perilaku moral para lulusan yang semakin hari cenderung semakin jauh dari tatanan nilai-nilai moral yang dikehendaki.

Untuk mengantisipasi persoalan semacam itu, pendidikan perlu direkonstruksi ulang agar dapat menghasilkan lulusan yang lebih berkualitas dan siap menghadapi "dunia" masa depan yang penuh dengan problema dan tantangan, serta dapat menghasilkan lulusan yang memiliki sikap dan perilaku moral yang mulia. Pendidikan harus mampu mengemban misi pembentukan kultur akhlak mulia (character building) sehingga para peserta didik dan para lulusan dapat berpartisipasi dalam mengisi pembangunan di masa mendatang tanpa meninggalkan nilai-nilai moral atau akhlak mulia.

Salah satu upaya untuk mewujudkan pendidikan seperti di atas, para peserta didik harus dibekali dengan pendidikan khusus yang membawa misi pokok dalam pembinaan akhlak mulia. Pendidikan seperti ini dapat memberi arah kepada para peserta didik setelah 
menerima berbagai ilmu maupun pengetahuan dalam bidang (jurusan) masing-masing sehingga peserta didik dapat mengamalkan ilmu di tengah-tengah masyarakat dengan tetap berpatokan pada nilai-nilai kebenaran dan kebaikan yang universal. Karena itulah, eksistensi pendidikan yang bernuansa akhlak mulia seperti Pendidikan Agama, khususnya Pendidikan Agama Islam (PAI) menjadi sangat penting. PAI tidak hanya untuk membekali para peserta didik dalam hal pengamalan nilainilai agama yang dianut, tetapi yang terpenting adalah mengantarkan peserta didik agar menjadi manusia yang berbudi pekerti luhur (berakhlak mulia). Pembelajaran Pendidikan Agama Islam (PAI) di sekolah maupun perguruan tinggi membawa misi pokok untuk terwujudnya manusia (peserta didik serta lulusan) yang memiliki akhlak mulia serta mampu mengamalkan ilmu dan keterampilan yang digelutinya dalam bentuk sikap dan perilaku tanpa meninggalkan nilai-nilai akhlak mulia tersebut.

Dalam rangka itu semua, penelitian tentang pembentukan kultur akhlak mulia di sekolah (termasuk dalam hal ini perguruan tinggi) penting dilakukan untuk melihat sejauhmana tingkat kebermaknaan misi yang diemban oleh kurikulum yang menjadi penyangganya. Penelitian ini bertujuan untuk mengungkap permasalahan pokok tentang bagaimana pembelajaran PAI di Universitas Negeri Yogyakarta (UNY) dapat berperan dalam pembentukan kultur akhlak mulia di kalangan mahasiswa dan problematika apa yang muncul dalam rangka pembentukan kultur akhlak mulia tersebut serta bagaimana alternatif pemecahannya. Untuk membahas permasalahan tersebut, perlu dikaji beberapa konsep di bawah.

\section{KONSEP PENDIDIKAN ISLAM}

Islam merupakan suatu agama yang ajaran-ajarannya bersumber dari wahyu Allah yang diturunkan kepada manusia melalui Nabi Muhammad Saw. sebagai Rasul-Nya. Dalam buku Islam Ditinjau dari Berbagai Aspeknya (1985), Harun Nasution menguraikan dengan panjang lebar berbagai segi dan ilmu yang menjadi cakupan Islam yang bersumber Al-Quran dan Sunnah (Hadis). Dari kedua sumber pokok ini para pemikir Islam berhasil mengambil berbagai ajaran atau konsep dalam berbagai aspek kehidupan manusia. Konsep yang terpenting dalam Islam adalah tauhid, yaitu ajaran yang menjadi dasar dari segala dasar dalam Islam, yakni pengakuan tentang adanya satu Tuhan, yaitu Allah (Nasution, 1985:30). Konsep-konsep lain yang terkandung dalam Islam adalah konsep hukum, konsep moral (akhlak), konsep politik, konsep sejarah, konsep filsafat, dan lain sebagainya.

Islam berbicara panjang lebar tentang pendidikan. Berkaitan dengan hal ini, M. Athiyah al-Abrasyi mengatakan bahwa inti pendidikan Islam adalah budi pekerti (akhlak). Jadi, pendidikan budi pekerti (akhlak) adalah jiwa pendidikan dalam Islam. Mencapai akhlak yang karimah (mulia) adalah tujuan sebenarnya dari pendidikan. Di samping membutuhkan kekuatan dalam hal jasmani, akal, dan ilmu, peserta didik juga membutuhkan pendidikan budi peker- 
ti, perasaan, kemauan, cita rasa, dan kepribadian (al-Abrasyi, 1987:1). Sejalan dengan konsep ini maka semua mata pelajaran atau mata kuliah yang diajarkan kepada peserta didik haruslah mengandung muatan pelajaran akhlak dan setiap guru atau dosen haruslah memerhatikan akhlak atau tingkah laku peserta didiknya.

Islam memberikan penghargaan yang tinggi terhadap ilmu, akan tetapi yang dimaksud adalah ilmu yang amaliyah. Artinya, seorang yang memperoleh suatu ilmu akan dianggap berarti apabila ia mau mengamalkan ilmunya. Terkait dengan hal ini, al-Ghazali (alAbrasyi, 1987:46) mengatakan bahwa manusia seluruhnya akan hancur, kecuali orang-orang yang berilmu. Semua orang yang berilmu akan hancur, kecuali orang-orang yang beramal. Semua orang yang beramal pun akan hancur, kecuali orang-orang yang ikhlas dan jujur. Al-Ghazali memandang pendidikan sebagai teknik atau skill, bahkan sebagai sebuah ilmu yang bertujuan untuk memberi manusia pengetahuan dan watak (disposition) yang dibutuhkan untuk mengikuti petunjuk Tuhan sehingga dapat beribadah kepada Tuhan dan mencapai keselamatan dan kebahagiaan hidup (Alavi, 2007: 312).

Sementara itu, Isma'il Raji al-Faruqi (1988:16) menegaskan bahwa esensi peradaban Islam adalah Islam itu sendiri, dan esensi Islam adalah tauhid atau pengesaan Tuhan, tindakan yang menegaskan Allah sebagai Yang Esa, Pencipta Yang Mutlak dan Transenden, dan Penguasa segala yang ada. Bagi kaum Muslimin, tidak dapat diragukan lagi, bahwa Islam, kebudayaan Islam, dan peradaban Islam memiliki esensi pengetahuan, yaitu tauhid (Q.S. al-Dzariyat (51): 56; al-Nahl (16): 36; al-Isra' (17): 23; al-Nisa' (4): 36; dan al-An'am (6): 151). Dengan demikian, ada tiga komponen penting yang harus diperhatikan di dalam mengelola pendidikan, yaitu ilmu itu sendiri, kemudian pengamalan ilmu tersebut, dan tauhid yang menjadi dasar utamanya. Kalau ketiga komponen ini tidak dipahami dan tidak diberikan secara integral, maka akan sulit tercapai tujuan pendidikan sebagaimana yang disebutkan di atas, yakni akhlak mulia.

\section{KONSEP AKHLAK MULIA DALAM ISLAM}

Kata akhlak berasal dari bahasa Arab al-akhlaq yang merupakan bentuk jamak dari kata khuluq yang berarti budi pekerti, perangai, tingkah laku, atau tabiat (Ya'qub, 1988: 11). Sinonim dari kata akhlak ini adalah etika dan moral. Secara terminologis, Ibnu Maskawaih mendefinisikan akhlak sebagai keadaan gerak jiwa yang mendorong ke arah melakukan perbuatan dengan tidak menghajatkan pikiran (Djatnika, 1996: 27). Sedang menurut al-Ghazali akhlak adalah suatu sifat yang tetap pada jiwa yang memungkinkan seseorang melakukan perbuatan-perbuatan dengan mudah dan seketika (Alavi, 2007: 313).

Akhlak merupakan salah satu dari tiga kerangka dasar ajaran Islam yang memiliki kedudukan yang sangat penting, di samping dua kerangka dasar lainnya, yakni aqidah dan syariah. Akhlak (baca: akhlak mulia) merupakan buah yang dihasilkan dari proses penerapan aqidah dan syariah. Ibarat ba- 
ngunan, akhlak merupakan kesempurnaan dari bangunan tersebut setelah fondasi dan bangunannya kokoh. Jadi, tidak mungkin akhlak ini akan terwujud pada diri seseorang jika tidak memiliki aqidah dan syariah yang memadai.

Nabi Muhammad Saw. bersabda dalam salah satu hadis yang berbunyi: "Sesungguhnya aku diutus hanyalah untuk menyempurnakan akhlak mulia" (HR. Ahmad). Hadis ini mengisyaratkan bahwa kehadiran Nabi Saw. di muka bumi ini membawa misi pokok untuk menyempurnakan akhlak manusia yang mulia.

Dalam al-Quran ditemukan banyak sekali pokok keutamaan akhlak yang dapat digunakan untuk membedakan perilaku seorang Muslim, seperti perintah berbuat kebajikan (al-birr) (QS. alMaidah (5): 2), menepati janji (al-wafa) (QS. al-Maidah (5): 1), sabar (QS. alBaqarah (2): 45), jujur (QS. al-Baqarah (2): 177), takut kepada Allah Swt. (QS. al-Baqarah (2): 189), bersedekah di jalan Allah, berbuat adil, dan pemaaf (QS. alBaqarah (2): 177; QS. al-Mu'minun (23): 1-11; QS. al-Nur (24): 37; QS. al-Furqan (25): 35-37; QS. al-Fath (48): 39; dan QS. Ali ‘Imran (3): 134). Ayat-ayat ini merupakan ketetapan dan ketentuan yang mewajibkan pada setiap orang Islam untuk melaksanakan nilai akhlak mulia dalam berbagai aktivitas kehidupannya. Keharusan menjunjung tinggi akhlak mulia lebih dipertegas lagi oleh Nabi Saw. melalui hadis-hadisnya.

Sumber untuk menentukan akhlak dalam Islam, apakah termasuk akhlak mulia atau akhlak tercela adalah alQuran dan Sunnah (Hadis). Baik dan buruk dalam akhlak, menurut Islam, ukurannya adalah baik dan buruk menurut kedua sumber itu, bukan baik dan buruk menurut ukuran manusia. Namun demikian, Islam tidak menafikan adanya standar lain selain al-Quran dan Sunnah untuk menentukan baik dan buruk akhlak manusia. Standar tersebut adalah akal dan nurani manusia serta pandangan umum masyarakat (adat/tradisi). Manusia dengan hati nuraninya dapat juga menentukan ukuran baik dan buruk, sebab Allah memberikan potensi dasar kepada manusia berupa tauhid (QS. al-A'raf (7): 172 dan QS. al-Rum (30): 30). Hati nuraninya selalu mendambakan dan merindukan kebenaran, ingin mengikuti ajaran-ajaran Allah Swt. dan Rasul-Nya karena kebenaran itu tidak akan dicapai kecuali dengan Allah Swt. sebagai sumber kebenaran mutlak. Namun demikian, harus diakui bahwa fitrah manusia tidak selalu dapat berfungsi dengan baik. Pendidikan dan pengalaman manusia dapat mempengaruhi eksistensi fitrah manusia itu (Ilyas, 2004: 4). Akal pikiran manusia dan tradisi juga sama kedudukannya seperti hati nurani.

Secara umum akhlak Islam dibagi menjadi dua, yaitu akhlak mulia (alakhlaq al-mahmudah/al-karimah) dan akhlak tercela (al-akhlaq al-madzmumah/alqabihah). Dilihat dari ruang lingkupnya akhlak Islam dibagi menjadi dua bagian, yaitu akhlak terhadap Khaliq (Allah Swt.) dan akhlak terhadap makhluq (selain Allah Swt.). Akhlak terhadap makhluk masih dirinci lagi menjadi beberapa macam, seperti akhlak terhadap sesama manusia, akhlak terhadap makhluk hidup selain manusia (seperti 
tumbuhan dan binatang), serta akhlak terhadap benda mati.

\section{PEMBENTUKAN KULTUR AKHLAK MULIA}

Kata kultur terambil dari kata berbahasa Inggris, culture, yang berarti kesopanan, kebudayaan, atau pemeliharaan (Echols dan Shadily, 1995:159). Dalam Kamus Besar Bahasa Indonesia kultur juga diartikan sama, yakni kebudayaan, pemeliharaan, atau pembudidayaan (Tim Redaksi KBBI, 2001:611). Kata kultur sekarang mulai banyak dipakai untuk menyebut budaya atau kebiasaan yang terjadi, sehingga dikenal istilah kultur sekolah, kultur kantor, kultur masyarakat, dan lain sebagainya.

Kultur Sekolah merupakan tradisi sekolah yang tumbuh dan berkembang sesuai dengan spirit dan nilai-nilai yang dianut sekolah. Tradisi itu mewarnai kualitas kehidupan sebuah sekolah. Oleh karena itu, nilai-nilai yang ditunjukkan dari yang paling sederhana, misalnya cara mengatur parkir kendaraan guru, siswa, dan tamu, memasang hiasan di dinding-dinding ruangan, sampai persoalan-persoalan menentukan seperti kebersihan kamar kecil, cara guru dalam pembelajaran di ruang-ruang kelas, cara kepala sekolah memimpin pertemuan bersama staf, merupakan bagian integral dari sebuah kultur sekolah (Depdiknas RI, 2004:11). Dengan demikian kultur merupakan kebiasaan atau tradisi yang sarat dengan nilai-nilai tertentu yang tumbuh dan berkembang dalam kehidupan sehari-hari dalam berbagai aspek kehidupan. Pembentukan kultur akhlak mulia berarti upaya untuk menumbuh-kembangkan tradisi atau kebiasaan di suatu tempat yang diisi oleh nilai-nilai akhlak mulia.

\section{METODE}

Penelitian ini merupakan penelitian deskriptif, karena penelitian ini hanya menggambarkan dan melukiskan suatu peristiwa tertentu, yang dalam hal ini adalah potret atau gambaran mengenai proses pembelajaran Pendidikan Agama Islam (PAI) di Universitas Negeri Yogyakarta (UNY) dalam rangka pembentukan kultur akhlak mulia di kalangan mahasiswanya. Penelitian ini bersifat kualitatif, karena penelitian ini mengungkap dan memahmi fenomena yang terjadi di sekitar pembentukan akhlak mulia di kalangan mahasiswa UNY melalui pembelajaran PAI. Adapun waktu penelitian mulai bulan April hingga bulan Agustus 2008.

Subjek penelitian dalam penelitian ini ditentukan secara purposive, yaitu pemilihan subjek penelitian secara sengaja oleh peneliti berdasarkan tujuan dan kriteria tertentu. Penentuan subjek penelitian didasarkan pada ciri-ciri atau karakteristik tertentu berdasarkan penilaian subjektivitas peneliti. Subjek penelitian yang dimaksud adalah para mahasiswa UNY yang sedang mengikuti atau mengambil mata kuliah PAI di semester genap tahun akademik 2007-2008. Karena demikian banyaknya jumlah mahasiswa UNY yang mengambil mata kuliah PAI, peneliti membatasi jumlah mahasiswa yang dijadikan subjek penelitian. Dalam penelitian ini peneliti hanya mengambil sampel sebanyak 100 mahasiswa dari tiga fakultas di UNY, yaitu yakni Fakultas Ilmu Pendidikan (FIP), Fakultas Matematika 
dan Ilmu Pengetahuan Alam (FMIPA), dan Fakultas Teknik (FT). Selain tiga fakultas tersebut, masih ada tiga fakultas lagi di UNY, yaitu Fakultas Ilmu Sosial dan Ekonomi (FISE), Fakultas Bahasa dan Seni (FBS), dan Fakultas Ilmu Keolahragaan (FIK). Sebagai key informan dalam penelitian ini adalah para dosen PAI yang memberi kuliah di tiga fakultas tersebut ditambah beberapa tutor PAI.

Dalam penelitian ini ada dua jenis data, yaitu data primer dan data sekunder. Data primer adalah data penelitian yang diperoleh secara langsung oleh peneliti melalui wawancara yang mendalam (in-depth interview) kepada para informan yang sudah ditentukan. Wawancara ditujukan kepada para dosen PAI yang mengajar di tiga fakultas di UNY, yakni FT, FIP, dan FMIPA. Wawancara juga dilakukan terhadap beberapa tutor PAI dan para mahasiswa yang sedang mengambil kuliah PAI. Agar wawancara lebih terarah, peneliti sebelumnya menyusun pedoman wawancara yang dapat digunakan sebagai acuan dalam wawancara ini. Peneliti juga menyebarkan angket kepada para mahasiswa untuk memperoleh informasi yang lebih general terkait dengan pembelajaran PAI di UNY. Di samping itu, peneliti juga menggunakan teknik dokumentasi untuk memperoleh data sekunder terkait dengan pembelajaran PAI di UNY. Data ini sudah diteliti oleh peneliti terlebih dahulu dan didokumentasikan dalam bentuk buku atau catatan-catatan mengenai permasalahan di sekitar pembelajaran PAI di UNY.
Teknik analisis data yang digunakan dalam penelitian ini adalah teknik analisis induktif. Teknik analisis induktif ini dilakukan dengan menganalisis permasalahan khusus di sekitar tradisitradisi yang berkembang di sekitar pembelajaran PAI dalam rangka pembentukan kultur akhlak mulia di kalangan mahasiswa UNY untuk selanjutnya ditarik kesimpulan yang bersifat umum dan objektif yang dapat menggambarkan permasalahan yang sebenarnya.

\section{HASIL DAN PEMBAHASAN \\ Pembelajaran PAI dan Pembentukan Kultur Akhlak Mulia di UNY}

Pendidikan agama di lembaga pendidikan baik sekolah maupun perguruan tinggi merupakan bagian integral dari pelaksanaan pendidikan yang diselenggarakan di lembaga pendidikan formal dan sekaligus menjadi bagian dari pendidikan nasional. Dalam UUD 1945 pasal 31 ayat 2 dinyatakan bahwa pemerintah menyelenggarakan satu sistem pendidikan nasional yang diatur dengan undang-undang.

Pasal 3 Undang-undang No. 20 Tahun 2003 tentang Sistem Pendidikan Nasional menegaskan, pendidikan nasional berfungsi mengembangkan kemampuan dan membentuk watak serta peradaban bangsa yang bermartabat dalam rangka mencerdaskan kehidupan bangsa, bertujuan untuk berkembangnya potensi peserta didik agar menjadi manusia yang beriman dan bertakwa kepada Tuhan Yang Maha Esa, berakhlak mulia, sehat, berilmu, cakap, kreatif, mandiri, dan menjadi warga negara yang demokratis serta 
bertanggung jawab. Dengan demikian, Pendidikan Agama merupakan bagian dari Pendidikan Nasional dan tujuan serta fungsi Pendidikan Agama adalah membantu terbinanya tujuan dan fungsi Pendidikan Nasional. Pada PP No. 55 Tahun 2007 tentang Pendidikan Agama dan Pendidikan Keagamaan pasal 2 ayat (1) juga ditegaskan bahwa Pendidikan agama berfungsi membentuk manusia Indonesia yang beriman dan bertakwa kepada Tuhan Yang Maha Esa serta berakhlak mulia dan mampu menjaga kedamaian dan kerukunan hubungan inter dan antarumat beragama.

Melihat demikian pentingnya Pendidikan Agama di sekolah dan perguruan tinggi sebagaimana dirumuskan dalam Undang-undang di atas, maka Pendidikan Agama, khususnya Pendidikan Agama Islam, memainkan peran dan tanggung jawab yang sangat besar dalam ikut serta mewujudkan tujuan pendidikan nasional, terutama untuk mempersiapkan peserta didik dalam memahami ajaran-ajaran agama serta melaksanakannya dalam kehidupan sehari-hari.

Untuk mewujudkan tujuan di atas, bukanlah hal yang mudah. Banyak persyaratan yang harus dipenuhi untuk membantu mewujudkan tujuan Pendidikan Agama di sekolah, di antaranya adalah yang terkait dengan status mata pelajaran Pendidikan Agama itu sendiri di sekolah, materi dan kurikulumnya, guru atau dosennya, peserta didiknya, metodologinya, sarana-prasarananya, dan lain sebagainya.

Perkuliahan PAI di UNY ditempuh dengan empat cara yang kesemuanya menjadi satu kesatuan, yaitu perkuliah pokok PAI di kelas, kuliah umum PAI, tutorial PAI, dan pesantren sehari. Perkuliahan pokok merupakan kegiatan pokok yang dilakukan oleh para dosen PAI yang berhadapan langsung dengan para mahasiswa di kelas. Kuliah umum PAI atau sering disebut Studium Generale PAI juga merupakan bagian penting dari perkuliahan PAI di UNY. Kuliah umum ini dikemas dalam bentuk seminar umum secara panel. Adapun tutotial PAI adalah rangkaian aktivitas perkuliahan PAI yang dikelola oleh para tutor PAI (mahasiswa senior) yang wajib diikuti oleh setiap mahasiswa yang sedang mengambil mata kuliah PAI. Program tutorial PAI dilaksanakan selama satu semester, baik semester gasal maupun genap, bersama-sama dengan pelaksanaan kuliah pokok PAI. Program tutorial PAI dimaksudkan untuk membantu para mahasiswa dalam penguasaan materi PAI, terutama terkait dengan konsep-konsep dasar PAI dan ibadah praktis. Rangkaian akhir dari perkuliahan PAI adalah pesantren sehari, yakni berupa kegiatan perkuliahan PAI yang dikemas seperti halnya pengajaran di pesantren.

Empat aktivitas itulah yang menjadi satu kesatuan dalam perkuliahan PAI di UNY. Dengan empat macam kegiatan itu diharapkan perkuliahan PAI tidak hanya sekedar memberi mahasiswa pemahaman tentang PAI (pencapaian kompetensi kognitif), akan tetapi yang lebih penting lagi adalah mahasiswa bisa memiliki kompetensi sikap dan perilaku yang dibentuk oleh pemahaman ajaran agamanya, yakni memiliki budi pekerti yang luhur atau akhlak mulia 
(pencapaian kompetensi afektif dan psikomotorik).

Tujuan akhir dari pembelajaran PAI yang hakiki sebenarnya bukan hanya para mahasiswa dapat menyelesaikan kuliah PAI dengan baik dan memperoleh nilai maksimal (misalnya A), tetapi yang sangat diharapkan bahwa pembelajaran PAI mampu mengantarkan mahasiswa memiliki pengetahuan yang cukup tentang PAI dan dapat mengamalkannya dalam kehidupan seharihari. Pengamalan ini bisa dalam hal pengamalan ketentuan hukum dalam Islam (syariah) dan juga pengamalan dalam hal sikap dan perilaku atau akhlak.

Untuk mengkaji pembentukan kultur akhlak mulia di UNY melalui mata kuliah PAI, bisa dicermati permasalahan penting di bawah ini.

\section{Peran Mata Kuliah PAI di UNY}

Mata kuliah PAI merupakan salah satu mata kuliah wajib yang harus diambil atau diikuti semua mahasiswa yang beragama Islam di seluruh program studi dan jurusan di UNY. Mata kuliah PAI yang secara khusus bermaterikan ajaran-ajaran inti dalam Islam bermuatan nilai-nilai akhlak (moral). Berdasarkan penelitian, semua mahasiswa UNY (100\%) menyatakan bahwa perkuliahan PAI memberikan manfaat bagi mahasiswa. Jawaban mahasiswa tentang rincian manfaat ini berbedabeda. Sebagian besar dari mahasiswa (90\% lebih) menyatakan bahwa PAI memberikan tambahan ilmu, khususnya tentang keislaman yang belum diperolehnya di jenjang pendidikan sebelumnya (SD-SMA). Mahasiswa juga menyatakan bahwa melalui kuliah PAI motivasi untuk beragama semakin bertambah terutama setelah memahami hakikat agama Islam. Mahasiswa mulai menyadari betapa pentingnya Islam untuk didalami dan diterapkan dalam kehidupan nyata.

Sebagai dosen PAI, peneliti bisa langsung mengamati proses pembentukan kultur akhlak mahasiswa, misalnya di awal perkuliahan mahasiswa masih belum begitu antusias dalam mengkaji ajaran-ajaran Islam, tetapi setelah mendapatkan motivasi yang cukup baik melalui kajian materi yang lebih mendalam maupun proses internalisasi yang dicobakan oleh dosen PAI, mahasiswa mulai bertambah antusias. Contoh yang lain dalam hal berpakaian, khususnya di kalangan mahasiswi, sering terjadi perubahan yang mencolok. Di awal perkuliahan, mahasiswi biasanya masih cukup banyak yang belum berbusana muslimah, tetapi di akhir perkuliahan mahasiswi sudah hampir semuanya berbusana muslimah, kecuali di fakultas-fakultas tertentu, misalnya di Fakultas Ilmu Kelolahragaan (FIK) dan Fakultas Bahasa dan Seni (FBS), terutama jurusan-jurusan seni.

Mahasiswa juga menyatakan bahwa salah satu kompetensi yang diperoleh dari perkuliahan PAI adalah dalam rangka pembentukan akhlak mulia. Ketika ditanyakan apakah di antara materi atau kompetensi yang ada dalam mata kuliah PAI bertujuan untuk pembentukan akhlak mulia, semua mahasiswa $(100 \%)$ menjawab "ya". Namun, mahasiswa berbeda-beda dalam memberikan rincian materi atau kompetensi apa saja yang memiliki tujuan pemben- 
tukan akhlak mulia. Ada yang berpendapat bahwa semua materi bermuatan akhlak mulia, namun yang menyatakan hal ini sangat sedikit (kurang dari 5\%). Sebagian besar dari mahasiswa (lebih dari $80 \%$ ) menyatakan bahwa materimateri yang bermuatan akhlak adalah materi tentang aqidah, syariah, dan akhlak. Adapun sebagian yang lain (lebih dari 10\%) memberikan jawaban yang bervariasi. Ada yang menekankan pada materi sumber-sumber ajaran Islam, takwa, toleransi umat beragama, Islam dan pendidikan, Islam dan psikologi, dan lain sebagainya. Perbedaan pandangan mahasiswa tentang materi atau kompetensi dalam PAI ini bisa beragam, mengingat masih beragamanya pemahaman mahasiswa tentang Islam.

Sebenarnya semua materi dalam PAI bermuatan akhlak, karena memang tujuan pembelajaran PAI bermuara pada terbentuknya akhlak mulia mahasiswa. Peneliti sendiri - sebagai dosen PAI - selalu menyelipkan pesan-pesan moral di setiap perkuliahan PAI dalam semua materi yang dikaji. Peneliti juga meminta semua mahasiswa untuk mencari satu artikel tentang Islam dari sumber mana pun lalu mahasiswa diminta untuk melakukan analisis sehingga terlihat pesan moral dari setiap artikel yang diambil dan sejauhmana mahasiswa sudah menerapkannya. Tugas ini sebenarnya untuk memotivasi mahasiswa agar tumbuh kesadaran dalam dirinya terkait dengan pesan-pesan moral yang ditangkap dari artikel yang Dianalisis.

Semua dosen PAI memang sudah sepakat bahwa semua materi dalam
PAI harus bermuatan akhlak mulia. Ini harus tercermin dalam setiap pembelajaran (kuliah) PAI tentang materi atau topik kajian apapun. Semua mahasiswa $(100 \%)$ juga menyadari akan hal ini. Mahasiswa dengan tegas menyatakan "ya", ketika ditanyakan kepadanya apakah dosen PAI selalu memerhatikan dan menyinggung tentang akhlak dalam setiap perkuliahan. Ini berarti bahwa perkuliahan PAI benar-benar mengarah pada pencapaian kompetensi yang tidak sekedar kognitif, tetapi yang terpenting adalah kompetensi afektif, yakni sikap dan perilaku mahasiswa (akhlak mulia). Namun, tujuan ini belum semuanya tercapai. Tampak bahwa para mahasiswa UNY belum semuanya menunjukkan sikap dan perilaku yang sesuai dengan nilai-nilai akhlak mulia. Banyak faktor yang bisa dijelaskan terkait dengan sikap dan perilaku mahasiswa seperti itu.

\section{Strategi Pembelajaran PAI dan Pem- bentukan Kultur Akhlak Mulia}

Pembelajaran mata kuliah PAI di UNY menggunakan strategi atau metode yang bervariasi, tergantung dosennya masing-masing. Namun demikian, ada beberapa kesepakatan yang dilakukan di antara dosen PAI untuk pembelajaran PAI di kelas, di antaranya terkait dengan strategi atau metode.

Dari wawancara yang peneliti lakukan dengan para dosen PAI terkait dengan strategi ini dapat dijelaskan seperti berikut.

- Metode yang digunakan di antaranya adalah ceramah dan diskusi (tanya jawab), diskusi kelompok dan diskusi kelas, penugasan, dan pene- 
laahan. Metode ini berbeda-beda frekuensi penggunaannya oleh masingmasing dosen PAI.

- Strategi atau cara yang dilakukan oleh dosen PAI dalam rangka pembentukan kultur akhlak mulia di kalangan mahasiswa juga berbeda-beda. Dari jawaban para dosen PAI terkait dengan hal ini dapat diidentifikasi sebagai berikut: (1) memulai dan mengakhiri dengan salam dan doa; (2) memerhatikan keaktifan mahasiswa dalam mengikuti kuliah, sehingga presensi mahasiswa menjadi bukti otentik untuk melihat hal ini; (3)memerhatikan pakaian yang dikenakan oleh para mahasiswa, terutama mahasiswa puteri (mahasiswi) dan jika mahasiswa belum mengenakan pakaian yang menutup aurat selalu diarahkan untuk memulai mengenakannya; (4) mengamati sikap dan perilaku mahasiswa di kelas ketika mengikuti kuliah atau berdiskusi termasuk dalam hal posisi duduk; (5) menanamkan pentingnya berakhlak mulia dalam kehidupan sehari-hari; (6) mengajak mahasiswa memberikan penilaian antar teman (peer evaluation) terkait dengan sikap dan perilakunya di kampus atau di luar kampus; (7) mengajak mahasiswa untuk selalu sportif (jujur dan disiplin), sabar, dan memiliki daya juang (dinamis); (8) di setiap kuliah mahasiswa diajak melakukan refleksi; dan (9) untuk memotivasi mahasiswa dibutuhkan juga keteladanan dari dosen PAI sendiri.

Itulah beberapa metode dan strategi yang digunakan oleh dosen PAI dalam pembelajaran PAI di kelas untuk pem bentukan kultur akhlak mulia di kalangan mahasiswa UNY. Di samping itu, para tutor PAI juga melakukan upaya pembentukan akhlak mulia dalam kesempatan tutorial PAI dengan mahasiswa, meskipun metode dan strateginya berbeda. Dalam tutorial mahasiswa lebih intensif mengkaji hal-hal praktis dalam pengamalan agama, mulai dari pemahaman dasar tentang al-Quran dan ibadah-ibadah mahdlah yang praktis, hingga penyadaranpenyadaran akan pentingnya berakhlak mulia. Melalui berbagai cara itulah para mahasiswa diarahkan untuk menjadi mahasiswa yang baik (muhsin), yakni yang berikap dan berperilaku mulia (berakhlak karimah).

\section{Penilaian Mata Kuliah PAI}

Dalam penilaian PAI, dosen tidak hanya memberikan nilai terpancang pada satu aspek penilaian saja, misalnya ujian semester (baik mid maupun akhir semester) saja. Dalam memberikan penilaian, dosen PAI melakukan penilaian yang berkesinambungan. Penilaian dilakukan mulai awal proses perkuliahan hingga akhir perkuliahan. Penilaian tidak hanya didasarkan pada satu aspek ranah saja, tetapi semua aspek ranah yang meliputi ranah kognitif, afektif, dan psikomotorik.

Penilaian berkesinambungan bisa dilakukan mulai dari kuliah pertama hingga kuliah terakhir dengan memerhatikan sikap dan perilaku mahasiswa di dalam ruang kuliah baik ketika memerhatikan penjelasan dosen, ketika bertanya, menyampaikan pendapat dalam diskusi, maupun keseriusan dan 
kedisiplinan dalam mengikuti perkuliahan. Sambil memberi kuliah, dosen dapat melakukan penilaian dengan mempertimbangkan berbagai aspek yang terkait. Cara bertutur kata maupun cara berpakaian dan penampilan mahasiswa sewaktu kuliah juga dapat dijadikan dasar untuk memberikan penilaian. Hal lain yang juga diperhatikan dalam penilaian PAI adalah presensi mahasiswa yang menunjukkan tingkat keaktifannya dan juga keaktifan dalam mengikuti tutorial yang hasilnya dilaporkan oleh para tutor PAI. Semua aspek inilah yang menjadi perhatian dosen PAI dalam memberikan penilaian tentang akhlak mahasiswa. Hasil penilaian akhlak seperti ini menjadi bagian penting yang bersama-sama dengan aspek penilaian lainnya, yakni hasil pembuatan makalah, presentasi, dan ujian semester, menjadi satu kesatuan nilai dalam penilaian PAI secara utuh (komprehensif).

Dengan demikian aspek moral menjadi bagian dari aspek penilaian yang sangat penting dalam pembelajaran PAI. Aspek-aspek moral seperti itu seharusnya juga menjadi bagian yang tidak boleh diabaikan para dosen mata kuliah lain dalam memberikan penilaian. Namun, tidak semua dosen menyadari dan memerhatikan hal tersebut, sehingga pada umumnya para dosen dalam memberikan penilaian lebih terpancang pada aspek atau ranah kognitifnya saja.

\section{Problematika Pembelajaran PAI di UNY}

Ada beberapa faktor yang berpengaruh dalam pembentukan kultur akhlak mulia di UNY, baik yang mendukung maupun menghambat. Di antara faktor pendukung untuk pembentukan kultur akhlak mulia di kalangan mahasiswa UNY adalah adanya tekad UNY untuk menjadikan lembaga UNY menjadi pioner dalam hal pembudayaan akhlak mulia atau pembentukan karakter. Ini dibuktikan dengan dirumuskannya visi UNY untuk membentuk insan yang cendekia, mandiri, dan bernurani. Dari visi ini jelas bahwa tekad UNY hingga tahun 2010 nanti adalah membangun insan UNY menjadi insan yang bernurani atau berakhlak mulia.

Adapun faktor penghambat dan masih menjadi problem dalam pembentukan kultur akhlak mulia, terutama melalui pembelajaran PAI di UNY sebagai berikut.

- Kemampuan dasar para mahasiswa yang mengikuti kuliah PAI sangat beragam. Heteroginitas kemampuan dasar para mahasiswa seperti ini cukup memberikan kendala dalam proses pembelajaran PAI sekaligus dalam pembentukan akhlak mulia. Poblem seperti ini harus diantisipasi dengan memberikan motivasi yang lebih terhadap mahasiswa yang masih kurang pemahamannya tentang Islam, misalnya memberikan tugas pengayaan kepada mahasiswa atau memaksimalkan fungsi tutorial PAI untuk membantunya agar tidak terlalu jauh perbedaan pemahamannya dengan yang lain.

- Kurangnya perhatian para mahasiswa terhadap masalah akhlak. Mahasiswa lebih termotivasi untuk memenuhi kriteria dalam rangka pencapaian nilai baik daripada untuk 
pembentukan akhlaknya. Karena itu, tidak sedikit di antara mahasiswa yang kuliah PAI mengenakan busana muslimah (bagi mahasiswi) tetapi setelah itu mengenakan busana lain (melepas jilbab) ketika tidak lagi kuliah PAI. Bahkan di antara mahasiswa, belum melakukan pengamalan agama yang cukup, misalnya masih ada yang belum aktif melakukan shalat wajib lima waktu atau kewajiban Islam yang lain. Kebiasaan di lingkungan keluarga dan masyarakat ikut berpengaruh besar dalam membentuk kebiasaan atau akhlak mahasiswa. Karena itulah dosen PAI memiliki tugas yang cukup berat dalam mengawal pembentukan akhlak mulia di kalangan mahasiswa. Di setiap kuliah, dosen PAI harus selalu menyentuh dan memotivasi mahasiswa dengan masalah akhlak.

- Materi pembelajaran PAI lebih banyak menekankan aspek kognitif. Jika diperhatikan materi ajar PAI di perguruan tinggi, khususnya di UNY, terlihat jelas sebagian besarnya adalah materi-materi untuk penguasaan aspek kognitif. Sangat sedikit materi PAI yang bermuatan aspek selain kognitif. Ini bukan berarti materi PAI itu tidak benar dan harus diganti semua. Lalu bagaimana seharusnya? Menyadari akan hal tersebut, dosen PAI harus benarbenar bisa mengemas perkuliahan PAI menjadi lebih bermakna dari sekedar memahami materi. Perkuliahan harus selalu diarahkan pada pembentukan akhlak mulia melalui materi yang dikaji. Hal yang terpenting bukan materinya apa, tetapi bagaimana materi itu bisa dijadikan dasar untuk memberikan penyadaran terhadap mahasiswa sehingga mampu membentuk akhlaknya.

- Kontrol terhadap mahasiswa di luar perkuliahan cukup sulit. Ini problem tersendiri dalam rangka pembentukan kultur akhlak mulia bagi mahasiswa. Kondisi yang cukup mempengaruhi pola sikap dan perilaku mahasiswa adalah lingkungan keluarga dan masyarakatnya. Kampus hanya memiliki waktu yang sangat sedikit tentang hal tersebut. Karena itu, kontrol dari keluarga dan masyarkat sangat dibutuhkan dalam rangka membangun sinergi untuk pembentukan kultur akhlak mulia bagi mahasiswa. PAI dalam hal ini memberikan kontribusi yang cukup besar kepada mahasiswa untukmembantu melakukan proses penyadaran tersebut. Dosen PAI dituntut untuk bisa memfasilitasi penyadaran mahasiswa melalaui perkuliahan yang kondusif melalui cara-cara atau strategi seperti yang sudah dikaji di atas. Mahasiswa diajak untuk menambah pemahaman tentang Islam dan terus dimotivasi untuk membiasakan diri dan mengamalkan ajaran-ajaran Islam sehingga mahasiswa berakhlak mulia.

\section{KESIMPULAN}

Berdasarkan hasil penelitian dan pembahasan seperti dipaparkan di atas, dapat ditemukan beberapa kesimpulan sebagai berikut

- Perkuliahan PAI di UNY ditempuh dengan empat cara yang kesemua- 
nya menjadi satu kesatuan, yaitu perkuliah pokok PAI di kelas, kuliah umum PAI, tutorial PAI, dan pesantren sehari.

- Pembelajaran PAI mempunyai peran yang sangat penting dalam rangka pembentukan kultur akhlak mulia di kalangan mahasiswa UNY. Pembelajaran PAI yang dikemas dengan baik dan didukung oleh dosen PAI yang berkompeten, input mahasiswa yang baik, materi yang memadai, serta metode dan strategi yang baik akan memberikan pengaruh yang besar dalam keberhasilan proses pembelajaran PAI, sehingga pembentukan kultur akhlak mulia di kalangan mahasiswa bisa terwujud dengan baik.

- Problematika yang muncul dalam pembelajaran PAI di UNY cukup banyak. Di antara problem yang muncul adalah kemampuan dasar mahasiswa UNY tentang PAI sangat beragam, perhatian mahasiswa terhadap masalah akhlak masih sangat kurang, materi pembelajaran PAI masih menekankan pada aspek kognitif, dan sulitnya melakukan kontrol terhadap mahasiswa di luar perkuliahan. Problematika ini harus diantisipasi dengan memaksimalkan fungsi dosen dalam pembelajaran PAI.

Akhirnya, penulis berharap penelitian ini memberikan kontribusi yang bermakna bagi pembaca umumnya dan penulis khususnya. Tidak lupa pula penulis mengucapkan terima kasih yang setulus-tulusnya kepada semua pihak yang membantu penelitian hingga terwujudnya tulisan ini.

\section{UCAPAN TERIMA KASIH}

Terima kasih diucapakan kepada DP2M Ditjen-Dikti yang telah membiayai penelitian ini. Selain itu, juga pihak-pihak terlait yang telah membantu terlaksananya penelitian ini. Terima kasih juga diucapkan kepada pengurus dan Redaktur Jurnal Cakrawala Pendidikan.

\section{DAFTAR PUSTAKA}

Al-Abrasyi, M. Athiyah. 1987. al-Tarbiyyah al-Islamiyyah - Dasar-dasar Pokok Pendidikan Islam. Terj. oleh H. Bustami A.Ghani. dan Djohar Bahry. Jakarta: Bulan Bintang.

Alavi, Hamed Reza. 2007. "Al-Ghazali on Moral Education". Jurnal of Moral Education. Vol. 36, No. 3, September 2007, pp. 309-319. ISSN 1465-3877 (online) 07/030309-11. London: Routledge Publisher.

Al-Faruqi, Isma'il Raji. 1988. Tawhid: Its Implications for Thought and Life Tauhid. Terjemah oleh Rahmani Astuti. Bandung: Pustaka.

Al-Kutub al-Tis'ah. CD Program Hadis Nabi Muhammad Saw.

Al-Qur'an al-Karim.

Depdiknas RI. 2004. Pengembangan Kultur Sekolah. Jakarta: Depdiknas RI.

Djatnika, Rachmat. 1996. Sistem Etika Islami (Akhlak Mulia). Jakarta: Pustaka Panjimas. 
Echols, M. John dan Hassan Shadily. 1995. Kamus Inggris Indonesia: An English-Indonesian Dictionary. Jakarta: PT Gramedia. Cet. XXI.

Ilyas, Yunahar. 2004. Kuliah Akhlaq. Yogyakarta: LPPI UMY. Cet. IV.

Nasution, Harun. 1985. Islam Ditinjau dari Berbagai Aspeknya Jilid I. Jakarta: UI Press, Cetakan V.

Tim Penyusun Kamus Pusat Bahasa. 2001. Kamus Besar Bahasa Indonesia. Jakarta: Balai Pustaka. Edisi 3 Cet. I.

Ya'qub, Hamzah. 1988. Etika Islam: Pembinaan Akhlaqulkarimah (Suatu Pengantar). Bandung: CV Diponegoro. Cet. IV. 